\title{
REVIEW
}

\section{How the Pernkopf Controversy Facilitated a Historical and Ethical Analysis of the Anatomical Sciences in Austria and Germany: A Recommendation for the Continued Use of the Pernkopf Atlas}

\author{
SABINE HILDEBRANDT* \\ Division of Anatomical Sciences, Office of Medical Education, University of Michigan Medical School, \\ Ann Arbor, Michigan
}

\begin{abstract}
Eduard Pernkopf's Topographical Anatomy of Man has been a widely used standard work of anatomy for over sixty years. International inquiries about the National Socialist (NS) political background of Eduard Pernkopf and the use of bodies of NS victims for the atlas were first directed at the University of Vienna in 1996. A public discussion about the further use of the book followed and led to the creation of the Senatorial Project of the University of Vienna in 1997. This historical research project confirmed the strong NS affiliation of Pernkopf and revealed the delivery of at least 1,377 bodies of executed persons to the Anatomical Institute of Vienna during the NS time. The possible use of these bodies as models cannot be excluded for up to half of the approximately 800 plates in the atlas. In addition tissue specimens from NS victims were found and removed from the collections of the Viennese Medical School and received a burial in a grave of honor. The Pernkopf controversy facilitated the historical and ethical analysis of the anatomical sciences in Austria and Germany during the NS regime. The continued use of the Pernkopf atlas is not only justifiable but desirable as a tool in the teaching of anatomy, history, and ethics. Clin. Anat. 19:91-100, 2006. @ 2006 Wiley-Liss, Inc.
\end{abstract}

Key words: NS history of German and Austrian anatomy; body acquisition; ethics in anatomy

\section{INTRODUCTION}

Eduard Pernkopf's Topographische Anatomie des Menschen (Topographical Anatomy of Man) has been widely used by students of anatomy since the publication of its first volume in 1937 (second volume 1942, third volume 1952, fourth volume 1956-1957, 1961; Williams, 1988) and the publication of the American edition in 1963 (Pernkopf, 1963). It stands out among similar works of anatomy for its intricacy and "regional stratigraphic" approach (Pernkopf, 1943), meaning multiple layers of dissection with an emphasis on fascia shown and reflected, approaching the subject from superficial to deep dissection in great detail. However, over the years inquiries have been made into the political background of Pernkopf and the illustrators of the atlas as well as into the source of the human bodies depicted. Pernkopf was an active NSDAP party member (Nationalsozialistische Deutsche Arbeiterpartei) and it was suspected that the victims of a criminal regime, which was ruling Austria from 1938 to 1945, were used for illustrations.

The question at the center of the Pernkopf controversy can be formulated as whether it is ethically justifiable to continue using the Pernkopf atlas, knowing that the work is tainted not only by being the creation

*Correspondence to: Dr. Sabine Hildebrandt, Division of Anatomical Sciences, Office of Medical Education, University of Michigan Medical School, 3767 Medical Science Building II, Catherine Street, Ann Arbor, MI 48109-0608.

E-mail: shilde@umich.edu

Received 31 August 2005; Revised 24 October 2005; Accepted 8 November 2005

Published online 19 January 2006 in Wiley InterScience (www. interscience.wiley.com). DOI 10.1002/ca.20272 
of scientists and artists who were ardent followers of a criminal regime, but also by the fact that these scientists may have been using the bodies of the victims of the Nazi regime for their endeavors.

The dilemma is made even more poignant by the fact that Pernkopf's atlas was and still is a very fine tool for anatomists and thus represents a rare example of Nazi medical scientists producing scientifically significant work (Riggs, 1998). In other medical fields, especially genetics and "race hygiene," NS scientific effort produced irrelevant results easily dismissible as an amalgam of science and pseudoscience (Propping, 1992; Mueller-Hill, 2004), so that an ethical question about their use does not even need to arise. However, anatomy and areas of public health and cancer research, as pointed out by Proctor (2000), make a detailed discussion of the use of Nazi scientific data necessary.

\section{PERNKOPF'S LIFE AND MIND}

An obituary written by his student and postwar successor, as Director of the Second Anatomy Institute in Vienna, Hayek (1955), sums up Eduard Pernkopf's life: he was born on 24 November 1888 in Rapottenstein near Zwettl, Austria, as the son of a physician and received his medical degree from the Vienna Medical School in 1912. As a third year medical student he started work as an anatomical demonstrator for Professor Ferdinand Hochstetter, director of the Second Anatomy Institute of Vienna, who subsequently made him his assistant. Research on the development of the gastrointestinal tract was the basis for his promotion to full professor in 1929, at that time he had already started work on his topographical atlas. In 1933 he succeeded Hochstetter as director of the Second Anatomy Institute. Hayek mentioned that Pernkopf, after becoming dean of the Medical Faculty in 1938 and later as rector, resisted commands for adaptation from Berlin. In what Hayek called Pernkopf's "retirement," after the end of the Second World War in a destroyed Vienna, he was offered rooms by members of the medical faculty to continue the work on his atlas. He died from a stroke on 7 April 1955. In conclusion Hayek praised Pernkopf as a lover of music and composer of an unpublished symphonic drama, a great teacher, researcher, and human being.

Hayek did not mention Pernkopf's political background at all, an omission typical for the postwar atmosphere in Germany and Austria (Mitscherlich and Mitscherlich, 1967; Neugebauer, 1998a; Wunder, 2000). Williams (1988) provided some insight after studying Pernkopf's Curriculum Vitae of 1940. With his enrollment in the Vienna Medical school in 1907
Pernkopf joined a nationalistic German student fraternity, Die akademische Burschenschaft Allemania. Pernkopf became NS party member in 1933 and joined the SA (Sturmabteilung $=$ stormtroopers) less than a year later. He was made director of the Second Anatomy Institute of Vienna in 1933. The Viennese Anatomy Institute had been divided into two departments in 1870 . Anatomy 1 , which was more systematically and clinically oriented, was led by liberal-democratic minded Jewish scientists until 1936, during Pernkopf's tenure by Julius Tandler. The chairmen of Anatomy 2 tended towards nationalism and anti-Semitism. During the 1920s and 1930s violent battles were fought between students from the two departments. In 1938 Anatomy 1 and 2 were reunited under the chairmanship of Pernkopf (Angetter, 1999). Williams describes Pernkopf as an obsessive worker and demanding supervisor, who developed his dissection and "imaging" techniques with the artisits early in his professional career, establishing a personal routine of $18 \mathrm{hr}$ work days that later focused completely on the atlas (Williams, 2004).

He was promoted to Dean of the Medical Faculty in April 1938, a few weeks after the Anschluss (the integration of Austria into Nazi Germany, 13 March 1938), and was Rektor Magnificus (president) of the University of Vienna from 1943 to 1945 . After the war he spent three years in an Allied prison camp but was then stripped of his titles and appointments, and allowed to return to the University of Vienna to continue work on the atlas. Articles by him continued to be published by the Wiener Klinische Wochenschrift (e.g., Pernkopf, 1955a,b), the journal whose editorial board he had joined in 1938 (Weissmann, 1985).

In his first lecture (Pernkopf, 1938) as Dean of the Medical Faculty in the new German Reich (6 April 1938), Pernkopf expressed his gratefulness towards Adolf Hitler, whom he called the émigré son of Austria, for the integration of Austria into the German Reich. He proclaimed the new goal of the Medical School as the education of German, i.e., National Socialist doctors, and explained that National Socialism was not just an idea but also a Weltanschauung (view of the world, conviction) that influenced and transcended science and allowed its application in actual deeds. He declared that a science that was marked by foreign, destructive, and "liberalistic" influences, and that invited chaos and promoted l'art pour l'art in music and the arts, and science for science's sake performed by vain and self-promoting scientists had come to an end. Instead he proposed a science of order, plan, direction, goal, and purpose: to serve life in general, the life of the individual and of the entire people. Specifically applied this Weltan- 
schaunng would allow the anatomical sciences to explain human variation through the concepts of constitution and race (in his postwar writings he still held on to this concept of variation but replaced the term "race" with the word "Menschengruppe," i.e., group of human beings, Pernkopf, 1955a). Pernkopf further demanded a new curriculum that included racial physiology, psychology, pathology, and racial genetics. Thus trained, the new doctor would be able to practically apply his knowledge in such areas as sports, occupational and family counseling, paternity and marital fitness questions and genealogical research (Ahnennachweis: usually the determination of racial origins for an Ahnenpass, a document needed for marriage under the NS regime). By these measures the doctor would serve not just the individual, but also the whole body of the people (Volkskoerper). To preserve and further the constitution of the body of the people, Pernkopf cited the means of positive selection by promotion of the healthy and worthy and their marriage and reproduction, as well as negative selection by extinction (Ausmerzung) of the unworthy and bad, prevention of racial mixing and elimination of the genetically inferior by sterilization and other means. He ended his lecture with a triple "Sieg Heil."

It should be mentioned at this point that Pernkopf, in his rhetoric of "negative selection," spelled out the steps that led directly from biological theory and Rudolf Hess' (Hitler's deputy) 1934 mandate of National Socialism being "applied biology" to the "other means" of the Holocaust (Lifton, 1986; Baeumer, 1990). He also showed himself as a proponent of the biologistic concept prevailing in the Nazi medical sciences that defined the individual human being only as a part of the total body of the people (Volkskoerper), thus allowing the removal of "diseased" individuals as a drastic but necessary cure to save the health of the body of the people (Volksgesundheit). Due to this biologistic definition, the term "disease" in National Socialism included not just the physically sick, but also the "unfit for the new society," the mentally ill, children born with malformations, homosexuals, social misfits, political opponents, and non-Arian racial groups like Jews and Sinti and Roma (European gypsies), who all could be subjected to the different methods of "negative selection" (Klee, 1985; Lifton, 1986; Baeumer, 1990; Weingart et al., 1992; Kroener, 1996; Seidelman, 1996).

\section{THE START OF THE CONTROVERSY}

In the 1980s, Williams (1982) and Weissmann (1985) reported on their research into the background of the Pernkopf atlas. A general interest in the world history of 1938 and medical history specifically led Weissmann (1985) to the political changes at the Vienna Medical School and its then new dean, Eduard Pernkopf, as documented in the Wiener Klinische Wochenschrift (Viennese Clinical Weekly Journal) of that year. Weissmann translated and commented on passages of Pernkopf's first lecture as dean that showed Pernkopf as an avid National Socialist.

In 1988, the first detailed investigation into the background of the creation of Pernkopf's atlas was published by David J. Williams, Professor of Medical Illustration at the School of Veterinary Medicine of Purdue University. During a sabbatical in Austria he studied more than 800 original paintings for the atlas and conducted interviews with Franz Batke, the then last living artist who contributed to the atlas. He reported that not only Pernkopf but also the major contributing illustrators Erich Lepier, Ludwig Schrott, Karl Endtresser and Franz Batke were active party members of the NSDAP or, with the exception of Lepier, at least participants in the Second World War. He saw evidence of the NS sympathies in the first edition of the atlas, as Lepier added a swastika to his signature in some of the plates created between 1938 and 1945, while Endtresser signed the double ss in his name in the shape of the typical lightening-bolt SS symbols (SS for Schutzstaffel, an elite Nazi troup).

Williams addressed the question of the origin of the human bodies shown in the illustrations citing evidence through personal correspondence that the use of victims from concentration camps was unlikely but that the Viennese Anatomy Institute regularly used victims of executions. After pointing out the superior quality of the anatomical illustrations Williams called the atlas a "troubled masterpiece."

In 1995 Edzard Ernst, former Chair of Physical Medicine and Rehabilitation at the Viennese Medical School, shed more light on the events in Vienna during the period from 1938 to 1945 and Pernkopf's involvement in them. He reported that Pernkopf, as dean of the medical faculty, was personally responsible for the removal of all faculty members who were of Jewish origin, married to Jews or political opponents, which led to the dismissal of 153 of the 197 members of the medical faculty. Most of these were able to emigrate, some were deported to concentration camps like Theresienstadt and Dachau, in which only a few survived. Others committed suicide and the fates of some are unknown (Muehlberger, 1998b). Ernst also claimed that Pernkopf used material from children killed in a Viennese hospital in his atlas and corpses of executed persons for teaching purposes.

In direct response to Ernst's publication, Panusch and Briggs (1995; Panush, 1996, 1997) asked their medi- 
cal center to remove the Pernkopf atlas from circulation and entered into a discussion with the distributors of the atlas. Hutton (1996), as spokesperson for the publisher Waverly Inc. for the German subsidiary Urban and Schwarzenberg, stated that they continued publishing the Pernkopf Anatomy "because of its scientific merit and the fact that, to date, no concrete evidence exists to substantiate Pernkopf's use of cadavers originating from Nazi concentration camp victims" in spite of their own inquiries into the matter, and that they tried to "separate Pernkopf, the man, from the work." The latter notion amused Gerald Weissmann (1997), who contended that Pernkopf would have "accused the defenders of his work for work's sake of "self-seeking narcissism" or "commercialism." Hutton stated that the publisher supported the request for an inquiry conducted by the University of Vienna, a request put to the Austrian authorities and the publishers by the Israel Holocaust and Martyrs Remembrance Authority, Yad Vashem, as reported by Israel and Seidelman (1996, 1997). The latter authors supported Yad Vashem's demand for a commemoration of potential victims of Nazi terror and an acknowledgement documenting the history of Pernkopf in future editions of the atlas, an opinion endorsed by Daniel Cutler, a medical illustrator at the University of Michigan (1997).

At this point in 1997, the University of Vienna (Ebenbauer and Schuetz, 1997) replied for the first time publicly by admitting to systematic suppression and even denial of its Nazi past and a lack of relevant investigations. The authors, as members of a new staff from a younger generation without NS ties, explained that this attitude had changed because of "increasing pressure from abroad" and a new political atmosphere in Austria after former Chancellor Vranitzky's public recognition of the responsibility of Austria for the events of 1938 to 1945 . They gave a preliminary report of facts ascertained and announced a research project named "The Anatomical Sciences 1938-1945."

From here a lively discussion developed in the general media (examples: The Michigan Daily Online, 1997; McManus, 1996; Williams, 1999).

\section{RESULTS FROM THE SENATORIAL PROJECT OF THE UNIVERSITY OF VIENNA}

The Senatorial Project of the University of Vienna dealt with two sets of facts; firstly with the origin and destiny of the bodies used by Pernkopf and secondly with the Nazi party membership and political activity of Pernkopf. Its design was based in part on one of the earliest historical self-analyses by an anatomical institute, the Anatomical Institute of the University of Tuebingen, Germany, 1990 (Malina and Spann,
1999). One goal of the project was to identify any remains of Nazi victims in the University collections so that they could receive a dignified burial as had been done in Tuebingen ("Graeberfeld X", Grueneklee, 2001).

To put the results of the Vienna project in historical perspective, it should be mentioned that over the centuries anatomical institutions had diverse sources for body acquisition. Human bodies were made available by government order in the case of unclaimed bodies, executed persons, those who committed suicide and the bodies of duelists; or they could be donated before death; in case of a lack of legal provisions human bodies also were stolen from cemeteries (Ball, 1928). In Vienna, anatomical dissections were routinely performed on executed persons since 1404, and in the eighteenth century Maria Theresia made the bodies of paupers available for this purpose (Angetter, 2000). By a decree from the Reichserziehungsminister (minister of education of the German Reich) of 18 February 1939, all bodies of executed prisoners were sent to the nearest department of anatomy (Malina and Spann, 1999; Angetter, 2000).

The use of the bodies of executed persons was a general practice in the German Anatomical Institutes during the NS regime (Aumueller and Grundmann, 2002; Redies et al., 2005), and was openly recorded in publications from this time period. For example, in research by the above-mentioned Pernkopf pupil, Heinrich von Hayek, who reported the use of lungs from executed persons and 5 gesunde Tonsillen von Hingerichteten (five healthy tonsils from executed persons) for his studies (Hayek 1941, 1942). Throughout his tenure Pernkopf was actively involved in the acquisition of cadavers for his institute, trying to find new sources of human bodies during the years of chronic lack of material before the implementation of the NS decree. In 1939 he suggested the transport of the bodies of executed persons from areas other than Vienna, namely Poland, but this question was apparently never pursued further. Instead, the influx of bodies from executions increased so much during the NS regime that the rooms of the anatomy institute were sometimes overfilled and executions had to be postponed because of this. Pernkopf was very much aware of these conditions as he applied for an increase of the institute's budget for 1943 on the basis of the rising number of cadavers to be handled (Muehlberger, 1998a). The bodies delivered to the Anatomical Institute of Vienna were used for dissection courses for medical students, preparation of specimens for teaching purposes, creation of long-term specimens for the anatomical collection and as models for the Pernkopf atlas (Malina and Spann, 1999). 
Concerning the origin of the bodies delivered to the Vienna Anatomical Institute from 1938 to 1945 the following facts were ascertained (Malina and Spann, 1999; Angetter, 2000). There were:

- 3,964 unclaimed or donated bodies from hospitals and geriatric and charitable institutions.

- About 7,000 bodies of fetuses and children: miscarriages, premature and stillborn babies.

- At least 1,377 bodies of executed persons (guillotined at the Vienna assize court or shot by the Gestapo at a rifle range), including eight of Jewish origin. The true numbers were not obtainable because of incomplete documentation.

- There was no evidence found that bodies from the concentration camp Mauthausen or the affiliated camp Gusen were brought to Vienna but such bodies seem to have been transported to the Anatomical Institute of Graz.

More than half of the executions had been carried out for political reasons. These included 526 verdicts of "high treason," whereby this could include offences reaching from active political opposition to such minor crimes as black-marketeering or listening to enemy broadcasts. Of the eight Jewish subjects, one was handed over to his family, whereas the other seven were delivered to the Anatomical Institute. The investigation of the anatomical collections at different institutes of the University of Vienna revealed the existence of specimens from NS victims that were then removed and interred in a grave of honor provided by the city of Vienna (Malina and Spann, 1999; Angetter, 2000).

In terms of Pernkopf's biography, the facts reported by Weissmann (1985), Williams (1988) and Ernst (1995) showing Pernkopf as an avid proponent of the NS ideology were verified by Malina (1997) and Malina and Spann (1999). Holubar (2000) quotes interviews with contemporaries of Pernkopf, including assistants and faculty who had been dismissed or imprisoned during the Nazi period, who described a man obsessed with his work and with little interest in anything else. Nevertheless Pernkopf was politically very active as Dean of the Medical School and President of the University. He helped establish an office for Erb- und Rassenbiologie (genetic and race biology) and did indeed make the changes in the medical curriculum that he had proposed in his first official speech as a dean (Pernkopf, 1938; Neugebauer, 1998b). After the war Pernkopf achieved a revision of his status as an "incriminated person" to a "lesser incriminated person" and thus easily passed the official "denazification" procedure, even receiving his full pension from 1953 until his death in 1955 (Malina and Spann, 1999; Angetter, 2000).

Of the artists working on the Pernkopf atlas, Erich Lepier was known to have an affinity for the Nazi regime (Angetter, 2000), and according to Williams (1988) had been an NS party member. After the Second World War Lepier continued to be a highly praised anatomical illustrator, who worked on the Sobotta/Becher "Atlas der Anatomie des Menschen" (Ferner and Staubesand, 1973; Atlas, 2001). Clemente used the Sobotta plates and "those subsequently drawn by Professor Erich Lepier of Vienna" (Clemente, 1975) to create a new single volume atlas. The self-taught anatomical artist was appointed professor in 1959 "in recognition of his contribution to science" (Urban and Schwarzenberg, 1977).

About half of the original 791 illustrations in the anatomical atlas were not created during the Nazi years as they either predate 1937 or were produced after 1945. Forty-one plates were definitely signed with dates from the Nazi period and it is likely that at least some of the models came from the group of 1377 executed victims. Of the remaining approximately 350 paintings the date of creation as well as the provenance of the bodies used as models is unclear (Angetter, 2000).

\section{IMPACT ON THE HISTORICAL AND ETHICAL DEBATE}

The "silence of words" as formulated by Howard Spiro in 1998 had finally been broken. Although a public discussion of the Nazi past of the clinical sciences in Germany had begun in the 1970s and become quite thorough throughout the years (Mueller-Hill, 1984; Lifton, 1986; Propping, 1992; Seidler, 2000; Klee, 2001; Mueller-Hill, 2004), the anatomical sciences lagged behind in this effort in Germany as well as in Austria; indeed, their NS history had not been written, as Malina and Spann noted in 1999. Early reports on the NS activities in Austrian Medical schools had not found a wide audience with the exception of the controversy surrounding Heinrich Gross, a Viennese physician implicated in NS euthanasia (Hubenstorf, 2000; Neugebauer, 1998a). In 1991 efforts by the German anatomist Aumueller to elucidate the NS history of German anatomy were not well received by his peers (Aumueller, 1991).

The critique by the Canadian Seidelman and Americans such as Israel and Weissmann concerning the lack of historical analysis of the origin of the Pernkopf atlas and its authors (Israel and Seidelman, 1996, 1997; Seidelman, 1996, 1999; Cutler, 1997) created a 
"push from the other side of the Atlantic and from Yad Vashem" (Holubar, 2000), that initiated a "belated [...] research into this shameful era" by the University of Vienna and its medical faculty (Ebenbauer and Schuetz, 1997; Schuetz et al., 1998; Malina and Spann, 1999).

In addition to this "push," several other factors contributed to a new openness towards the discussion of the Nazi past and ethics in anatomy in Germany and Austria in recent years:

1. The simple fact of time passing, so that most of the former Nazi scientists, many of whom had been active in postwar German and Austrian medicine had died. Now it is up to the "children and grandchildren" (Wunder, 2000) to elucidate the past so as not to be "condemned to repeat it" (Santayana, 1905).

2. The change of the general political climate in Austria initiated by the international controversy in the 1980s surrounding former president Kurt Waldheim's NS affiliation (Neugebauer, 1998a). This was a change in so far as the country did not represent itself any longer only as a victim of the Nazi regime but also as a collaborator in Nazi crimes (Ebenbauer and Schuetz, 1997).

3. The ethical debate concerning body acquisition and demonstration in the anatomical sciences has become very active in Germany after the controversial "Body World" exhibitions by Gunther von Hagens (who at one time was a faculty member at the University of Heidelberg) in the 1990s (Peuker and Schulz, 2004; Wetz and Tag, 2001; Roebel and Wassermann, 2004). Anatomists, philosophers, artists, lawyers, physicians, theologians, sociologists, and journalists all have taken part in a very public discussion that led to Gunther von Hagen's decision to stop his exhibitions in Germany, but also contributed to new legislation regarding the use of human bodies, organs and tissues (Juette, 2003).

Unexpected outcomes of the Viennese studies were, on the one hand, the great extent of new historical facts concerning NS activities and crimes committed. On the other hand, the investigations revealed the need for a new ethical debate in the Austrian medical establishment concerning the use of bodily remains of human beings (Angetter, 2000). The studies led the University of Vienna to the decision to create a new position for a Professor of History of Medicine with an emphasis on newer history that is now held by Michael Hubenstorf (Neugebauer, 2001).

The Pernkopf controversy gave not only an important impulse for a thorough historical and ethical anal- ysis of the anatomical sciences in Austria, but it seems to have facilitated similar analyses in Germany. Several new historical analyses of German anatomical institutes, e.g., in Marburg and Jena, have been published recently and refer to the Pernkopf discussion and the Viennese investigations (Aumueller and Grundmann, 2002; Redies et al., 2005).

The discussion surrounding Gunther von Hagens' exhibits, especially his use of human bodies from questionable sources (Peuker and Schulz, 2004; Working, 2005), underlines the relevance of the historical and ethical analysis of Nazi scientists like Pernkopf and their methods on the background of this history. This is another example of the experience that the exploration of the Nazi past of Germany and Austria can still lead to important insights into not only past but also current ethical questions. It is certainly not yet time to look away from this history as suggested by Walser (1998). It is the "failure of attention to relatively subtle matters of ethics, [...] a failure of analysis [...] rather than the lack of compassion or deliberate callousness" (Marcia Angell as quoted by Malina, 1997) that can lead to unethical research today.

\section{APPROACHES TO A SOLUTION OF THE PERNKOPF CONTROVERSY}

From the beginning of the debate there have existed two diametrically opposed views about the further use of the Pernkopf anatomical atlas. These have been documented by Atlas (2001) who commented on the ethics of the Pernkopf controversy from a librarian's point of view, by Max Kamien, Professor of General Practice at the University of Western Australia (Williams, 1999) and the then-first year resident physician Garrett Riggs (1998), who summarized philosophical analyses of the conflict. Indeed, the Pernkopf debate has become a case study in educational curricula for librarians and students of philosophy (examples: Field, 1999; Marcuse, 2002; GSLIS, 2005).

On the one side there are authors like Panush and Briggs (1995), who would like to see the Pernkopf atlas removed from all libraries. Arguments for the complete banishment include the following:

- The fundamental evil included in the creation of the atlas.

- The fact that nobody should profit from the exploitation of human life, especially of victims of the NS regime.

- The view that the active use of results from research by NS scientists could justify the atrocities committed. 
- The idea that a work cannot be separated from its creator, thus if the creator is evil, the work is too.

- The belief that the use of NS data might initiate society's slide down a "slippery slope" towards Nazi-like amorality.

- The opinion that the Pernkopf Atlas is easily replaceable by other anatomical atlases or more modern means of medical imaging (e.g., the Visible Human Project at the US National Library of Medicine).

On the other hand there is a group of authors (i.e., Atlas, 2001) who argue for a continued use of the Pernkopf atlas, preferably in its original form including the NS symbols as a historical document and with the addition of a historical note commenting on the origin of the work. Their arguments include:

- The opinion that good may derive from evil in providing new doctors with the means to perform better operations.

- The view that victims of the NS regime and their sacrifice are best honored by a continued use of the atlas.

- The idea that the publication of the atlas in its original form including NS symbols and information about the historical context can be used not only for the anatomical but also ethical and historical education of future physicians.

- The fact that the elimination or suppression of books is a symptom of totalitarian systems as evidenced in the NS book burnings.

- The opinion that the atlas is a work of great aesthetic value.

On balance it is justifiable to continue using Pernkopf's book. To see the atlas as a masterwork of greatest aesthetic value or as the evil manifestation of a science only capable to be performed by Nazis (Paterniti, 2003) seems to ascribe this book too much power. The atlas is neither a work of supernatural beauty nor of supernatural evil but the product of the very human mind of an obsessive perfectionist who would have pursued his work under any political circumstances. Indeed, the first and the last parts of the atlas were not created during the time of the NS regime in Austria but before and after under very different political and material conditions. The fact remains that Pernkopf and some of the artists were guilty of being Nazis. Pernkopf, as many other German and Austrian anatomists (Aumueller, 1991), was also guilty of profiting from the abundance of human bodies provided by the criminal NS regime through executions, a fact of which he was very much aware. There is no evidence that he directly contributed to anyone's execution. It is unclear how many of the paintings in the atlas show the bodies of NS victims, but the exact number seems of no consequence when compared with the crime that the bodies of NS victims were used at all. If Pernkopf's book was banned because of his and the artists' NS membership the same reasoning would have to apply for the Sobotta/Becher and Clemente atlases because of Lepier's contribution to them, not to mention popular German anatomy textbooks like Voss/ Herrlinger that were created by authors with NS affiliations (Aumueller, 1991). Also, a ban could not atone the great evil committed by human beings on other human beings. Rather, it is up to a new human generation to glean good from this murky history by continuing to use Pernkopf's atlas in a rational, historically conscious manner.

It is not only justifiable but also desirable to continue using Pernkopf's atlas for two reasons. Firstly, the statement about the easy replacement of the Pernkopf atlas by other anatomical atlases cannot be maintained from an anatomist's point of view. The atlas is still one of the very best in terms of accuracy, showing levels of detail concerning fascia and neurovascular structures that are of direct relevance for the actual dissection process. The anatomical sciences cannot easily dismiss any existing work of anatomical imaging, as all these different approaches of imaging function in a complementary, not mutually exclusive manner. Anatomical paintings and drawings cannot be replaced by radiographs, computed tomograms, plastinated models, or other methods; rather, they all work together in describing human anatomy by providing multiple aspects of the same subject in different manners of presentation, thereby addressing the various ways of reception of information in any student of anatomy. Likewise the Visible Human Project provides completely new information of human anatomy that will enhance, but not replace, older traditional works. Secondly, the Pernkopf paintings can “... serve a double role: more than teaching anatomy, they remind us of the horror that any "objective" science can impose.[...] The crimes of the Nazi doctors teach us what we physicians must not do" (Spiro, 1998). The lessons to be learned from Pernkopf's methods include not only generally the need for careful scrutiny of relations between academic institutions and government but more specifically the need for closer examination of the sources of body acquisition in modern anatomy. The relevance of this topic is obvious not only in the discussions surrounding Gunther von Hagens" "Body Worlds" but also the Visible Human project. The person who became the 
first Visible Human was an executed murderer who had willed his body to the Texas Anatomy Board (Atlas, 2001). Ethical questions about the use of bodies from victims of capital punishment, even though this particular body was donated, certainly need further discussion. Pernkopf's story is an object lesson for modern anatomy in that the inquiry into the sources of human bodies cannot be too careful and that rigorous standards have to be formulated and followed.

Meanwhile, the publisher Elsevier GmbH, Urban \& Fischer Verlag, has stopped the publication of the Pernkopf atlas citing the possible use of NS victims for the creation of the atlas as the reason for this decision (Hubbard, 2001, and personal communication from the editorial director of Elsevier GmbH, Urban \& Fischer Verlag, 9 August 2005). In addition, Williams reports that on reexamination of the original paintings in Munich in 2002 he found that the swastikas had been painted out of some originals and other paintings had been repainted (Paterniti, 2003; Williams, 2004). Even if a historical-critical edition of the original paintings has become impossible, a new edition with the addition of a historical annotation seems a reasonable option for the solution of the Pernkopf controversy. Such an edition could be used for teaching not only anatomy, but also history and ethics.

\section{ACKNOWLEDGMENTS}

The author thanks David J. Williams (Purdue University) for helpful discussion.

\section{REFERENCES}

Angetter DC. 1999. Die Wiener anatomische Schule. Wien Klin Wochenschr 111:764-774.

Angetter DC. 2000. Anatomical science at the University of Vienna 1938-45. Lancet 355:1445-1457.

Juette R. 2003. Arbeitskreis "Menschliche Praeparate in Sammlungen”. Empfehlungen zum Umgang mit Praeparaten aus menschlichem Gewebe in Sammlungen, Museen und oeffentlichen Raeumen. Deutsches Aerzteblatt 8:378-383.

Atlas MC. 2001. Ethics and access to teaching materials in the medical library: the case of the Pernkopf atlas. Bull Med Libr Assoc 89:51-58.

Aumueller G. 1991. Die Anatomie in der NS-Zeit. In: Bis endlich der langersehnte Umschwung kam... Von der Verantwortung der Medizin im Nationalsozialismus. Fachschaft Medizin der Philipps-Universitaet Marburg (eds.), p 87112.

Aumueller G, Grundmann K. 2002. Anatomy during the Third Reich: The Institute of Anatomy at the University of Marburg, as an example. Ann Anat 184:295-303.

Baeumer A. 1990. NS-Biologie. Stuttgart: S. Hirzel Wissenschaftliche Verlagsgesellschaf. p 91-102,214.
Ball JM. 1928. The body snatchers: Doctors, grave robbers and the law. reprint 1989, New York: Dorset Press.

Clemente CD. 1975. Anatomy: A regional atlas of the human body. Preface. Munich: Urban und Schwarzenberg.

Cutler DS. 1997. Origins of the Pernkopf anatomy atlas. JAMA 277:1122.

Ebenbauer A, Schuetz W. 1997. Origins of the Pernkopf anatomy atlas: In reply. JAMA 277:1123-1124.

Ernst E. 1995. A leading medical school seriously damaged. Ann Intern Med 122:789-792.

Ferner H, Staubesand J. 1973. Sobotta/Becher: Atlas der Anatomie des Menschen. Vorwort zur 16. Auflage. Muenchen, Berlin, Wien: Urban und Schwarzenberg.

Field R. 1999. Northwest Missouri State University: A practical guide to ethical theory: V. Deontological ethical theory. URL: http://info.nwmissouri.edu/ rfield/274guide/274overview5.htm [accessed June 2005].

Grueneklee U. 2001. Du sollst erinnern: Wie die Universitaet Tuebingen der Opfer der NS-Diktatur gedenkt. URL: http://www.uni-tuebingen.de/uni/qvo/at/attempto11/att11_ culture3.html [accessed August 2005].

Hayek Hv. 1941. Ueber arterio-venoese Anastomosen und die postcapillaren Venen der menschlichen Tonsille. Z Anat Entwicklungsgesch 111:533-544.

Hayek Hv. 1942. Kurz- und Nebenschluesse des menschlichen Lungenkreislaufes in der Pleura. Z Anat Entwicklungsgesch 112:221-228.

Hayek Hv. 1955. Prof. Dr. Eduard Pernkopf. Wien Klin Wochenschr 67:350.

Holubar K. 2000. The Pernkopf story: The Austrian perspective of 1998, 60 years after it all began. Perspect Biol Med 43:382-388.

Hubbard C. 2001. Historical note: Eduard Pernkopf's atlas of topographical and applied human anatomy: The continuing ethical controversy. Anatomical Rec 265:207-211.

Hubenstorf M. 2000. Anatomical science in Vienna, 1938-45. Lancet 355:1385-1386.

Hutton EB Jr, 1996. Nazi origins of an anatomy text: The Pernkopf atlas. In reply. JAMA 276:1634.

Israel HA, Seidelman WE. 1996. Nazi origins of an anatomy text: The Pernkopf atlas. JAMA 276:1633.

Israel HA, Seidelman WE. 1997. Origins of the Pernkopf atlas: In reply. JAMA. 277:1123.

Juette R. 2003. Pressemitteilung anlaesslich der Vorstellung der "Empfehlungen zum Umgang mit Praeparaten aus menschlichem Gewebe in Sammlungen, Museen und oeffentlichen Raeumen.” Press conference June 23, 2003 Berliner Medizinhistorisches Museum, Berlin.

Klee E. (ed.) 1985. Dokumente zur "Euthanasie". Frankfurt am Main: Fischer Taschenbuchverlag GmbH.

Klee E. 2001. Deutsche Medizin im Dritten Reich. Karrieren vor und nach 1945. Frankfurt am Main: S. Fischer Verlag $\mathrm{GmbH}$.

Kroener P. 1996. Die Umgestaltung der Ethik: Das Los zukuenftiger Generationen und die "Volksgemeinschaft". In: Kolb S, editor. Fuersorge oder Vorsorge? Medizin zwischen Patientenwohl and Volksgesundheit. Frankfurt am Main: Fischer Taschenbuch Verlag GmbH. p 47-64.

Lifton RJ. 1986. Aerzte im Dritten Reich. German Edition 1998. Berlin: Ullstein Buchverlag GmbH \& Co. KG. p $46 \mathrm{ff}$. 
Malina P. 1997. Eduard Pernkopfs Anatomie oder: Die Fiktion einer "reinen" Wissenschaft. Wien Klin Wochenschr 109: 935-943.

Malina P, Spann G. 1999. Das Senatsprojekt der Universitaet Wien "Untersuchungen zur Anatomischen Wissenschaft in Wien 1938-1945”. Wien Klin Wochenschr 111:743-753.

Marcuse H. 2002. Pernkopf's atlas: ethics of choice. University of California, Santa Barbara. http://www.history.ucsb.edu/ faculty/marcuse/classes/33d/33d02/33d02Lectures/33d02113. htm [retrieved 13 June 2005].

McManus R. 1996. A tainted classic: anatomy text draws criticism. NIH record. Sept 24 1996; 48(0). quoted from URL: http://www.nih.gov/news/NIH-Record/09 24 96/story01. htm [accessed June 2005].

Mitscherlich A, Mitscherlich M. 1967. Die Unfaehigkeit zu trauern. Grundlagen kollektiven Verhaltens. 15th Ed. 1998. Muenchen: Piper Verlag GmbH. p 9.

Muehlberger K. 1998a. II. Die Belieferung des anatomischen Instituts der Universitaet Wien mit Studienleichen in der Zeit von 1938-1946. In: Akademischer Senat der Universitaet Wien, editor. Senatsprojekt der Universitaet Wien: Untersuchungen zur anatomischen Wissenschaft in Wien 1938-1945. p 29-66.

Muehlberger K. 1998b. Enthebungen an der medizinischen Fakultaet 1938-1945. Wien Klin Wochenschr 110:115-120.

Mueller-Hill B. 1984. Toedliche Wissenschaft. Reinbek bei Hamburg: Rowohlt Taschenbuch Verlag, GmbH.

Mueller-Hill B. 2004. Reflections of a German scientist. In: Catalogue of the exhibit: Deadly medicine: Creating the master Race, United States Holocaust Museum. Chapel Hill, NC: University of North Carolina Press. p 185-199.

Neugebauer W. 1998a: Zum Umgang mit der NS-Euthanasie in Wien nach 1945. Presentation at Symposion "Zur Geschichte der NS-Eunthanasie in Wien”. Wien, 29/30 Jan 1998. URL: http://www.doew.at/thema/thema alt/justiz/euthjustiz/gross.html [accessed June 2005].

Neugebauer W. 1998b. Racial Hygiene in Vienna 1938. Wien Klin Wochenschr, Sonderheft, March 1998. URL: http:// www.doew.at/information/mitarbeiter/beitraege/rachyg.html [accessed June 2005].

Neugebauer W. 2001. NS-Medizin in Oesterreich: Bruch oder Kontinuitaeten? URL: http://www.doew.at/thema/ns medizin/ neugeb.html [accessed May 2005].

Panush RS. 1996. Nazi origins of an anatomy text: the Pernkopf atlas. JAMA 276:1633-1634.

Panush RS. 1997. Origins of the Pernkopf Atlas. JAMA 277:1123.

Panush RS, Briggs RM. 1995. The exodus of a medical school. Ann Intern Med 123:963.

Paterniti M. 2003. The most dangerous beauty. In: American Society of Magazine Editors (de.). The best American magazine writing 2003. New York: HarperCollins. p 2-31.

Pernkopf E. 1938. Nationalsozialismus und Wissenschaft. Wien Klin Wochenschr 51:545-548.

Pernkopf E. 1943. Topographische Anatomie des Menschen. I. Band: Allgemeines, Brust und Brustgliedmasse. Berlin: Urban und Schwarzenberg. p 7.

Pernkopf E. 1955a. Die Wegbereitung und der Charakter der modernen Anatomie. Wien Klin Wochenschr 67:312-315.

Pernkopf E. 1955b. Gedanken, die einer allgemeinen, funktionellen Anatomie des Nervensystems vorangestellt werden koennen. Wien Klin Wochenschr 67:341-344.
Pernkopf E. 1963. Atlas of topographical and applied human anatomy. Volume 1: Head and neck, 1963. Volume 2: Thorax, abdomen and extremities, 1964. Philadelphia and London: W.B. Saunders Co.

Peuker T, Schulz C. 2004. Der ueber Leichen geht. Berlin: Ch. Links Verlag.

Proctor RN. 2000. Nazi science and Nazi medical ethics: some myths and misconceptions. Perspect Biol Med. 43:335-346.

Propping P. 1992. Was muessen Wissenschaft und Gesellschaft aus der Vergangenheit lernen? In: Propping P, Schott H, editors. Wissenschaft auf Irrwegen, BiologismusRassenhygiene-Eugenik. Bonn, Berlin: Bouvier Verlag. p 122- 125 .

Redies C, Viebig M, Zimmermann S, Froeber R. 2005. Origin of corpses received by the Anatomical Institute at the University of Jena during the Nazi regime. Anatomical Rec (Part B: New Anat) 285B:6-10.

Riggs G. 1998. What should we do about Eduard Pernkopf's atlas? Acad Med 73:380-386.

Roebel S, Wassermann A. 2004. Haendler des Todes. Der Spiegel. 19:36-50.

Santayana G. 1905. Life of reason, reason in common sense. New York: Scribner. p 284. URL: http://iupui.edu/ santedit/ \#quota [accessed August 2005].

Schuetz W, Holubar K, Druml W. 1998. On the 60th anniversary of the dismissal of Jewish faculty members from the Vienna Medical School. Wien Klin Wochenschr 110:113-114.

Seidelman WE. 1996. Nuremberg doctors' trial: Nuremberg lamentation: for the forgotten victims of medical science. BMJ 313:1463-1467.

Seidelman WE. 1999. Medicine and Murder in the Third Reich. Jewish virtual library. URL: http://www.jewishvirtuallibrary. org/jsource/Holocaust/medmurder.html [accessed May 2005].

Seidler E. 2000. Kinderaerzte 1933-1945 entrechtet - geflohen - ermordet. Bonn: Bouvier Verlag.

Spiro HM. 1998. The silence of words: some thoughts on the Pernkopf atlas. Wien Klin Wochenschr 110:183-184.

The Graduate School of Library and Information Science (GSLIS, University of Illinois at Urbana-Champaign). 2005. Case Study: Pernkopf Atlas. URL: http://www.lis.uiuc.edu/ [accessed August 2005].

The Michigan Daily online. 1997. Vienna University apologizes for Nazi involvement, plans investigation, 13 February 1997. URL: http://www.pub.umich.edu/daily/1997/feb/0213-97/news/news20.html [accessed June 2005].

Urban and Schwarzenberg. 1977. The Urban \& Schwarzenberg Collection of Medical Illustrations since 1896. Baltimore, Munich: Urban \& Schwarzenberg.

Walser M. 1998. Rede zur Ueberreichung des Friedenspreises des deutschen Buchhandels in der Frankfurter Paulskirche, 11 Oktober 1998. URL: http://de.wikipedia.org/wiki/Martin Walser. [accessed August 2005].

Weingart P, Kroll J, Bayertz K. 1992. Rasse, Blut und Gene: Geschichte der Eugenik und Rassenhygiene in Deutschland. Frankfurt am Main: Suhrkamp. p 1-26.

Weissmann G. 1985. Springtime for Pernkopf. Hosp Pract (Office Edition) 20:142-168, reprinted in Weissmann G. 1987. They all laughed at Christopher Columbus. New York: Times Books. p 48-69.

Weissmann G. 1997. Origins of the Pernkopf anatomy atlas. JAMA 277:1122. 
Wetz FJ, Tag B. (eds.) 2001. Schoene Neue Koerperwelten. Stuttgart: Klett-Cotta.

Williams DJ. 1982. The work of Eduard Pernkopf, et al. 37th Annual Meeting of the Association of Medical Illustrators, Anaheim, CA, October 13, 1982.

Williams DJ. 1988. The history of Eduard Pernkopf's Topographische Anatomie des Menschen. J Biocommun 15:2-12.

Williams DJ. 2004. Is a picture worth a thousand lives? The truth about the most beautiful book you will never see. The twenty-third annual Charles Henry Hackley distinguished lecture in the humanities. Muskegon, Michigan, May 20, 2004.
Williams R. 1999. Nazi Science, transcript of a radio program: Ockham's Razor 29 August 1999. URL: http://www.abc. net.au/rn/science/ockham/stories/s47540.htm [accessed June 2005].

Working R. 2005. Shock value. Gunther von Hagens has outraged critics with macabre publicity stunts to promote "Body Worlds" and lure 17 million visitors to the exhibit worldwide. It's all in the service of science, he says. Chicago Tribune, July. 31: 2005.

Wunder M. 2000. Medicine and conscience: the debate on medical ethics and research in Germany 50 years after Nuremberg. Perspect Biol Med 43:373-381. 